\title{
A Review of Alternative Building Materials for Sustainable Construction Towards Sustainable Development
}

\author{
Johnson Josiah MARUT ${ }^{1 *}$ John Okwe ALAEZI ${ }^{2}$, Igwe Christopher OBEKA ${ }^{3}$ \\ ${ }^{1}$ Department of Building, Faculty of Environmental Sciences, University of Jos \\ ${ }^{2}$ Department of Building, Faculty of Environmental Sciences, Baze University, Abuja \\ ${ }^{3}$ Industrial and Technology Education Department, Building Technology Section, \\ Federal University of Technology, Minna
}

* Corresponding author email: josiahmarut@gmail.com

Received: 30 September 2020 / Revised: 12 November 2020 / Accepted: 28 November 2020 / Published: 29 December 2020

\begin{abstract}
The study reviewed Alternative Building Materials for sustainable construction towards sustainable development. The study was able to identify some Alternative Building Materials, their features, classes (types) and importance for sustainable construction toward sustainable development. The study uses systematic literature review and content analysis. Some of the Alternative Building Materials include laterite soil, brick wastes, rice husk ash burnt refuse ash, fly ash, periwinkle shell powder, earthworm cast, pulverized burned clay, periwinkle shell aggregate, tubali, earth/mud blocks or bricks, laterite blocks, bamboo for roofing \& ceiling, palm front roofing, clay/mud plaster. The classes of the Alternative Building Materials include: modified conventional industrial materials, unconventional/ indigenous/ traditional materials, and modified unconventional/traditional indigenous materials. The features of sustainable construction materials include recyclability, insulation and thermal conductivity and deconstruct ability, availability, manufacturing and price, flexibility and high life time expectancy. The importance of Alternative Building Materials includes: the protection of the environment through reduce energy use and also cutting down $\mathrm{CO}_{2}$ emission, provision of affordable housing, energy conservation, meeting increasing demands for housing stock, provision of employment opportunities, the development and propagation of indigenous technological ingenuity and skills of our local people. The study advocates for the integration of the entire stakeholders in the construction industry towards utilisation of Alternative Building Materials for sustainable construction towards sustainable development. The study also advocates for the cataloguing of all Alternative Building Materials so as to create awareness to all the potential clients and stakeholders of the industry regarding their availability and importance.
\end{abstract}

Keywords: Alternative Building Materials, Sustainable Construction, Sustainable Development

\section{Introduction}

The construction industry is the second largest consumer of raw materials after the food processing industry[1]. Materials are the essential components of buildings construction [2]. The building construction materials must be sustainable for both the present and future generations [3]. As a result, there has been a surge of interest in developing Alternative Building Materials which are capable of meeting our structural needs with lower energy and material consumption[2]. The global trend towards increased environmental awareness and climate change has resulted in a surge of interest in ecologically friendly building materials. Much of the global demand for housing is currently being driven by economic growth in developing countries. Alternative building materials can play a vital role in the Nigerian building construction industry however; there is the need to understand what constitute the term Alternative Building 
Materials. Alternative Building Materials are building materials that are developed through modifying conventional industrial materials or unconventional / indigenous / traditional materials or modifying unconventional / traditional / indigenous materials which are particularly attractive for housing [4]. The major advantages of these materials over conventional materials typically include a low embodied energy (often leading to reduced embodied greenhouse gas emissions), ease of construction, widespread availability and low cost. These properties make alternative housing technologies attractive not only for housing in the developed countries, but also for use in humanitarian engineering projects in developing countries [5]. Some of the Alternative Building Materials that are sustainable in nature according to [6] includes: straw bale, bamboo, manufactured sand, ferrock and C\&D waste to mention but a few. There is therefore, the need to understand the sustainable construction aspect of these materials. Alternative Building Materials have essential element of good building materials that is, avoidance of problematic substances in the construction that can adversely affect the environment, health, and recycling opportunities [7].

The construction industry has been slow to respond to the corporate responsibility but increasing regulation in areas such as carbon emissions and waste are forcing companies to improve their processes and many clients are beginning to demand responsible building materials [8]. There is the need for improving the way that businesses respond to the needs of stakeholders and ensure the sustainability of their activities. This means that it is relevant for companies of all sizes within the industry supply chain, including clients, designers, contractors and the suppliers of materials to begin to consider the sustainability of building materials being supplied to the building construction industry. The use of sustainable building materials represents a way for the construction industry to contribute to protecting the environment, and has become the key point to minimize the environmental impact and achieve sustainable development [9].

Materials selection is among the top five issues affecting the achievement of sustainable construction towards sustainable development, choosing sustainable materials is critical in reducing environmental impact [10]. Other issues that affect the achievement of sustainable development according to[10] are: Corporate Responsibility (CR), Environment, Community, and Accident and Incidents. In 2000, 189 countries of the world came together to face the future, in terms eliminating extreme poverty and hunger in the world, diseases, mortality and protection of the environment. The inability of the United Nations (UN) to achieve Millennium Development Goals (MDGs) which was planned in 2000 with the goals to be achieved by the year 2015 but only a little was achieved which has now led to the formulation of 17 Sustainable Development goals (SDGs), the goals include the following: Goal 1: No poverty Goal 2: Zero hunger Goal 3: Good health and well-being Goal 4: Quality education Goal 5: Gender equality Goal 6: Clean water and sanitation Goal 7: Affordable and clean energy Goal 8: Decent work and economic growth Goal 9: Industry, innovation and infrastructure Goal 10: Reduced inequalities Goal 11: Sustainable cities and communities Goal 12: Responsible consumption and production Goal 13: Climate action Goal 14: Life below water Goal 15: Life on land Goal 16: Peace, justice and strong institutions Goal 17: Partnerships for the Goals [11]. The goals that are of concern to this study are goals 11,12 and 13 because they are responsible for development of housing in both rural and urban centers as it also relates to climate change. As building construction materials are produced or manufactured it affect both human beings as well as the environment therefore the need for the manufacture of materials that are sustainable that will not cause negative impact to the environment in terms of carbon emission which can lead to global warming, all alternative building materials are sustainable because they are found within the environment and have a negligible amount of embodied energy [12] . 


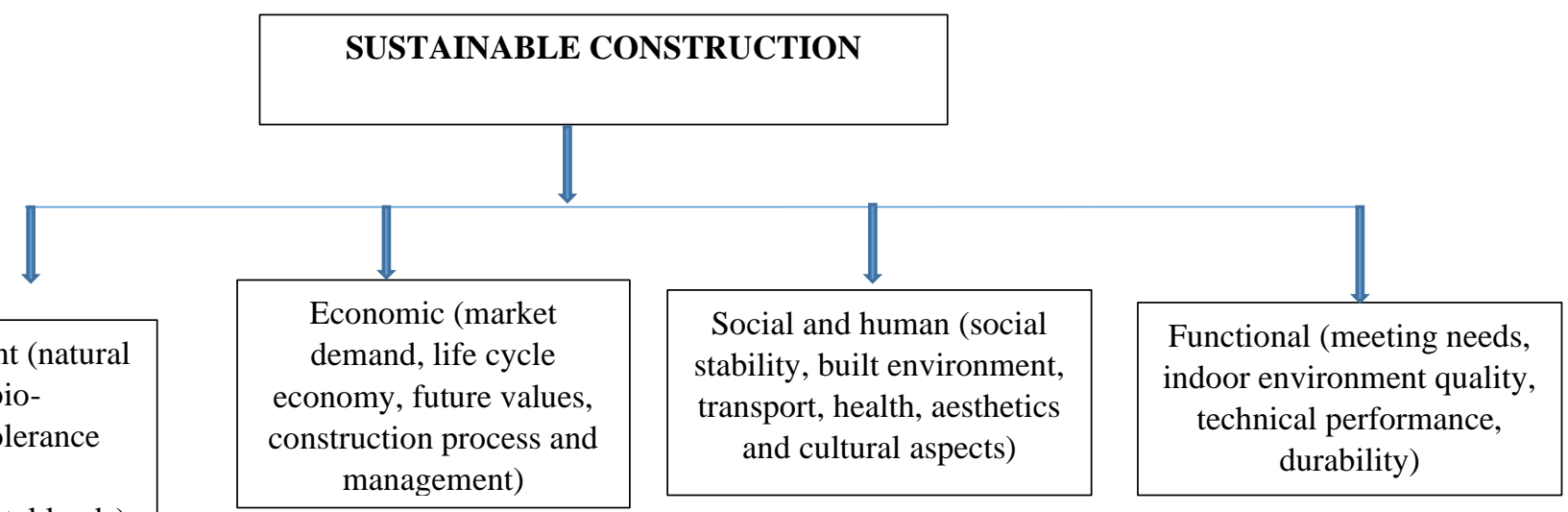

Figure 1: The four main facets of sustainable construction [8]

Sustainable construction needs the adoption of building materials that are environmentally friendly [13]. It also means using materials and resources that have sustainable supplies and are readily available from many sources. While BCA [14] defined sustainable construction as the adoption of materials and products in buildings and construction that would require less use of natural resources and increase the reusability of such materials and products for the same or similar purpose, thereby reducing waste as well.

Sustainable construction should enhance the resilience of the industry as such materials are readily available in the world market. For the achievement of sustainable construction there is a need for sharing of knowledge and expertise in the use of such materials. Sustainable construction consists of four facets (Figure1) which include environment (natural resources, bio-diversity, tolerance of nature, environmental loads), economic (market demand, life cycle economy, future values, construction process and management), social and human (social stability, built environment, transport, health, aesthetics and cultural aspects) and functional (meeting needs, indoor environment quality, technical performance, durability)[3]. An example of sustainable building material is stabilised blocks, which can be use in place of conventional fired bricks and can significantly reduce the energy use and also cut down $\mathrm{CO}_{2}$ emissions and minimize generated waste. The terms high performance, green, and sustainable construction are often used interchangeably; however, the term sustainable construction most comprehensively addresses the ecological, social, and economic issues of a building in the context of its community [15].

Furthermore, sustainable building materials are materials which are domestically created and sourced which decreases transportation costs and $\mathrm{CO}_{2}$ emissions, they could consist of reused materials, they possess a lower environmental effect, they are thermally effective, they need less energy than conventional materials, they make use of renewable resources, they are lower in harmful emissions and they are economically sustainable [16]. The purpose of sustainable construction activities is to avoid resource depletion of energy, water, and raw materials and to prevent environmental degradation caused by facilities and infrastructure throughout their life cycle [13]. Therefore, the focus of today's environmental policy is to be on material efficiency. Here waste prevention and recycling/reuse play a key role by providing huge energy, water and material savings. The goal of sustainable construction according to [3] is creating and operating a healthy built environment based on resource efficiency and ecological balance. As important as sustainable construction is it cannot be achieved without understanding what sustainable development is. Sustainable development is the global understanding of the urgency of addressing the many comingled economic, social and environmental issues standing in the way of development, the greening of economies and 
improvements in human well-being, quality of life and happiness [13].

This research is based on sustainability theory, [17] which attempt to prioritise and integrate social responses to environmental and cultural problems. An economic model looks to sustain natural and financial capital; an ecological model looks to biological diversity and ecological integrity; a political model looks to social systems that realise human dignity. The overall aim of the Sustainable Development Goals (SDGs) is to provide guidance and contribute effectively to transformative changes "in support of a rightsbased, equitable and inclusive approach to sustainability at global, regional, national and local levels[18]. In agreement [19] also stressed that the general goal of sustainable development is to meet the essential needs of the world's poor while ensuring those future generations have adequate resources base to meet theirs. The Sustainable Development Goals that concern the construction industry include: Structurally transform economies and attain inclusive sustained economic growth; accelerate infrastructure development, industrialization and access to affordable energy; and build resilient cities and sustainable human settlements and enhance the quality, resilience and protection of the environment; and promote sustainable exploitation, use and management of natural resources[20]. Therefore, to achieved these lofty initiatives there is the need to review the various Alternative Building Materials for the sustainable building construction towards the achievement of the goals of sustainable development towards meeting the housing needs.

There is the need to establish the justification for the review of ABM for sustainable construction towards sustainable development. The research is basically a systematic literature review of the Alternative Building Materials for sustainable construction towards sustainable development through the identification of Alternative Building Materials [21].This is because of the evident global warming caused by the manufacture of conventional construction building materials and its impact on human beings, animals as well as the environment. The need for the literature review is to bring to the fore what sustainable construction is, identify the basic principles of sustainable construction and identify also the materials that can help towards the achievement of sustainable construction for sustainable development in Nigeria, in which Alternative Building Materials can serve this purpose [22]. The literature review as a methodology is very important for this study because it has provided an over view of areas in which the research is disparate. In addition, it is an excellent way of synthesizing research findings to show evidence on a meta-level and to uncover areas in which more research is needed, which is a critical component of creating theoretical frameworks and building conceptual framework[23]. Systematic review is also for synthesizing both quantitative and qualitative studies [24].

Through the review of the ABM for sustainable construction towards sustainable development the gap in terms of the knowledge needed as well as inadequate experienced can bridged. This study is aimed at systematically reviewing Alternative Building Materials for sustainable construction towards sustainable development; with the view to achieve the following objectives: to identify Alternative Building Materials for sustainable construction toward sustainable development; to evaluate the classes (types) of Alternative Building Materials for sustainable construction; to determine the features of sustainable building construction materials towards sustainable construction; and to evaluate the importance of Alternative Building Materials for sustainable construction towards sustainable development.

\section{Identification of Alternative Building Materials for Sustainable Construction Toward Sustainable Development.}

Housing problems being experienced by people in Nigeria could be reduced drastically with the use of Alternative Building Materials such as laterite that is durable, culturally accepted, economical and not risky to human health [25]. It could also be used to achieve sustainable housing for all in terms of quality and quantity. 
Johnson Josiah Marut et al., J. Mod. Mater.; Vol. 7, Issue 1, pp: 68-78, 2020

Some Alternative Building Materials found in Nigeria include adobe, bamboo, thatch, stones, timber, coconut tree and grasses to mention but a few [26]. Abundant deposits of clay, laterite, stone, lime, agro-industrial waste, timber, bitumen, glass sand etc., in their natural state in Nigeria complements the call for the use of these local materials for building construction purposes [27]. Pozzolanas are very good innovations in material production and utilisation in the building industry, they are siliceous and alumious materials which in themselves possesses little or no cementitious value but will, in finely divided form and in the presence of moisture, chemically react with calcium hydroxide at ordinary temperatures to form compounds possessing cementitious properties [28]. The utilisation of pozzolans brings about economic, environmental and technical advantages. The technical advantages involve the improvement of the quality of concrete i.e improved workability, improved resistance to sulphate attack, reduced alkali-aggregate reaction, reduced heat of hydration and thermal shrinkages and increase in water tightness. Some of the pozzolanas include: Rice Husk Ash (RHA), Fly Ash (FA), Ground Husk Ash (GHA), Pulverised Burnt Clay (PBC), Saw Dust Ash (SDA), Acha Husk Ash (AHA). The mixture of quarry dust and lateritic soil can give best performance when compared with the mixture of red earth and river sand+laterite + red earth) (RLR) when used as an Alternative Building Materials to river sand in the production of sandcrete blocks [29]. Most professionals in the construction industry tend to agree that the use of Alternative Building Materials (ABM) contributes positively to the environment particularly in its protection [30].

Some of the barriers to the use of Alternative Building Materials according to the researchers include: poor clients' interest, public perception, poor social acceptability, doubtful durability and life span, as well as lack of standard and specification. A lot of researches has been carried out on conventional building materials and catalogued however alternative building materials in Nigeria have not being given the right attention in spite of their enormous advantages. Research has shown that experts perceive natural building materials as 'low-tech' and poor in performance[31]. Nevertheless, experts' skeptical attitude toward natural building materials is caused by a) lack of knowledge, b) lack of experience, and c) cultural bias [32], [33], [34]. The extraction and utilisation of conventional construction building material has led to increase in global warming, this is due to high amount of energy needed for their manufacturing [33]. There is the need for research world-wide in construction materials development, an alternative necessitated by high price of conventional materials, difficulty in accessing financial resources for construction/building development, the need to recycle agricultural waste materials for construction, the bio-degradability of the materials, the need to maintain ecological balance and population growth and the challenges of housing amongst the many other reasons [35]. These materials are cheap relative to the imported materials from outside the country [31]. They are found to promote cultural heritage, they are available and affordable, they are energy efficient, reusable, and biodegradable among others as the major advantages of Alternative Building Materials, which all have met the basic requirements for sustainable construction [26].

\section{Evaluation of Classes (Types) of Alternative Building Materials for Sustainable Construction}

A review of numerous researches in construction materials suggest that the development of Alternative Building Materials takes one of the three main forms. Either conventional material are modified with the main objective of reducing their cost or modifications are directed towards improving unconventional materials, which constitute the group of alternative materials and their properties are studied with a view of incorporating them in present day construction [4]. Partial replacement and substitution of some constituents, compression, stabilization and reinforcements are among the main methods of altering the original materials as shown figure 2 . 


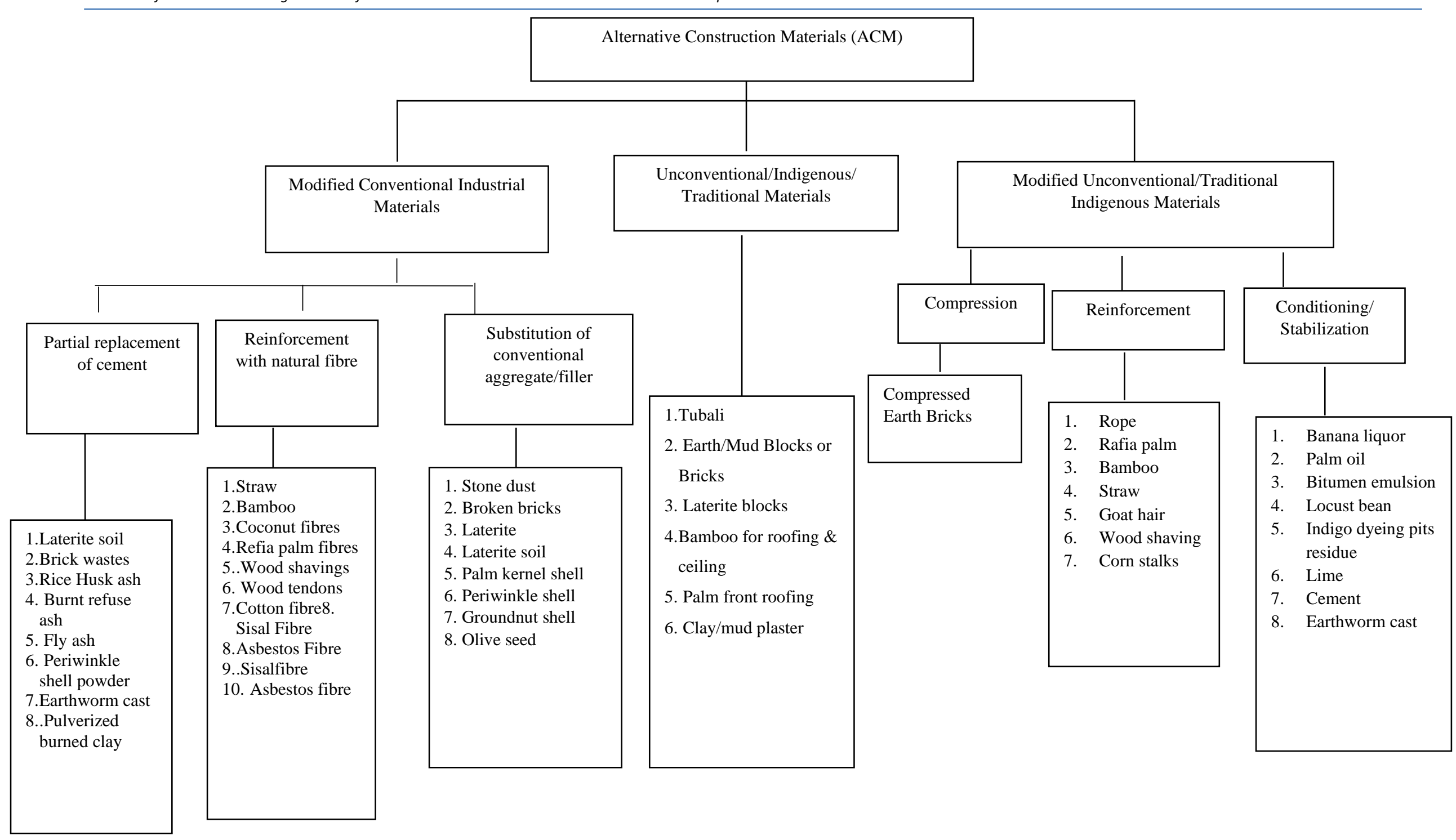

Figure 2: The classes (types) of Alternative Building Materials for sustainable construction [4]. 
Johnson Josiah Marut et al., J. Mod. Mater.; Vol. 7, Issue 1, pp: 68-78, 2020

Most of the research aim at reducing the cost of construction materials but begin and end up eventually with testing strength and a few other properties of resulting materials without any meaningful studies of economic implications of the innovations [4]. The materials can be used for the following: Substructure/foundation; earth laterite when well treated and stabilised with cement, bitumen, limes, reeds, can be used to achieve desirable strip foundation; Flooring, laterite reinforced with bamboo or coconut palm, laterite mixed with desirable workability and reinforced with reeds can be rammed as oversite on a well compacted stone hardcore, cow dung when properly mixed with clay screening produced strong and good looking floor; wall and structural frames, baked brick, brick with laterite, stone jointed with laterite mortar or lime stabilised mortar, coconut palm, bamboo and timber treated as a stakes inside earth form a desirable building wall; roofing, timber coconut palm, pale and stake when treated can be used as roof trusses and post/column and finishes/fittings, earth stabilised with cement form a good plastering materials, stones, core and bamboo. Rice Husk Ash, Soil Bitumen Brick and Micro Concrete Roofing Tiles are Alternative Building Materials that can be incorporated for construction in Nigeria which agreed with other previous findings based on engineering requirement, production and maintenance cost, transportation cost, availability, optimum time of production and durability [31]. Researchers have been able to identify some Alternative Building Materials that can be used for the achievement of sustainable construction towards sustainable development, the materials include: Laterite soil, Brick wastes, Rice Husk ash, Burnt refuse ash, Fly ash, Periwinkle shell powder, Earthworm cast, Pulverized burned clay, Straw, Bamboo, Coconut fibres, Refia palm fibres,. Wood shavings, Wood tendons, Cotton fibre. Sisal Fibre, Stone dust, Broken bricks, Laterite, Laterite soil, Palm kernel shell, Periwinkle shell, Groundnut shell, Olive seed, Tubali, Earth/Mud Blocks or Bricks, Laterite blocks, Bamboo for roofing \& ceiling, Palm front roofing, wood, Clay/mud plaster, Compressed Earth Bricks, Banana liquor, Palm oil, Bitumen emulsion,
Locust bean, Indigo dyeing pits residue, Lime, Cement and Earthworm cast. It is important to mention here that some of these materials are still subject to scientific testing of the mechanical properties as seen on figure 2. Based on the above discussion, there are three types of Alternative Building Materials which include: modified conventional industrial materials, unconventional/indigenous/ traditional materials and modified unconventional/traditional indigenous material [4].

\section{$4 \quad$ Features of Alternative Building Materials Towards Sustainable Development}

The construction industry manufactures the built environment and it puts in place a physical stock of facilities and infrastructure that determines our degree of freedom and flexibility for anything up to 100 years after construction. Sustainable development is the challenge of meeting human needs for natural resources, industrial products, energy, food, transportation, shelter and effective waste management, while conserving and protecting environmental quality and the natural resource base for future development[31]. Sustainable construction involves reducing the environmental impact of the building over lifetime, while optimising its economic viability [6]. Similarly, sustainable construction is the creation and responsible management of a healthy built environment based on resource efficient and ecological principles [36]. Studies on sustainable construction materials are on the rise with their environmental, social, and economic benefits [37].

Sustainable material is part of sustainable development [12]. This means that Alternative Building Materials can play a very important role in the achievement of sustainable development because of the high level housing deficit in Nigeria which is due to the cost of conventional building materials. There two features for sustainable building materials these are: ecological features which include: recyclability, contamination, insulation and thermal 
conductivity and deconstructability; economic features which include: availability, manufacturing and price, flexibility and life time expectancy [38]. While [12] explained that the acid test for considering building materials to be sustainable, the building materials should satisfy the following criteria: the material should be renewable and resource efficient; the material should support environmental health. In other words, it should provide healthier environment to public. Indoor air quality should be excellent; the material should be appropriate for application for which it is proposed to be used and should be economical to use. Similarly, three major indicators of sustainable building materials include: environmental indicators which comprises of human toxicity, climate change, and solid waste; social indicators which include adaptability, thermal comfort, local resources, and housing for all; economic indicators which comprises maintenance cost, operational cost, initial cost, long-term savings, and life span [39].

For indoor utilisation, we must ensure that the material: does not emit volatile organic compound VOCs; low emission of toxic or carcinogenic or irritant chemicals and free of toxic materials such as chlorine, lead, mercury, arsenic, chromium, cadmium, asbestos, chlorinated polyethylene and chloro-sulphonated polyethylene, Chlorofluorocarbons (CFC), polyvinyl chloride (PVC), halogenated flame retardants, phthalates, creosote, penta-chloro phenol, petrochemical fertilizers and pesticides as well as formaldehyde [4]. The incorporation of waste materials from industrial processes or households into usable building products reduces the waste stream and the demand on virgin natural resources.

Some features of sustainable building construction materials as stressed by [40] include: they should be healthy for the users; they shouldn't consume energy for transportation, thus avoiding collateral pollution; they shouldn't consume a great quantity of energy for fabrication; high insulation qualities, in order to avoid excessive energy consumption; eventually the new materials and techniques should have beneficial effects on the environment; vegetation in buildings is indicated; they should be recyclable; they should be reusable at least once, or even several times and they should reuse residues; the reuse of non-ecological materials can be an ecological undertaking. The principles of sustainable construction stressed by [3] include: reduce resource consumption (reduce); reuse resources (reuse); use recyclable resources (recycle); protect nature (nature); eliminate toxics (toxics); apply life-cycle costing (economics) and focus on quality (quality).

All the researchers on the features of sustainable construction materials towards sustainable development have shown that Alternative Building Materials must have the following features in no particular order: ecological features which include: recyclability, low contamination, insulation and thermal conductivity and deconstructability, economic features which include: availability, manufacturing and price, flexibility and life time expectancy, environmental features which include: protection of nature (environment), environmental health (free of toxic substances, non or low emission of volatile organic compound), low pollution. Social features which include: aesthetics and cultural value and acceptability and functional features which include: low energy consummation, indoor air quality should be excellent, technical performance and durability.

\section{Importance of Alternative Building Materials for Sustainable Construction}

The use of Alternative Building Materials in the Nigerian building construction industry: drivers and barriers stressed by emphasied that Alternative Building Materials ensures the provision of environmentally friendly materials, provision of a source of study and research for both present and future generation, enlarging and promoting the economic strength of people and the country at large, provision of affordable housing, energy conservation alternative, meeting increasing demands for housing stock, provision of employment opportunities, the development and propagation of indigenous technological ingenuity and skills of the local people. 
Johnson Josiah Marut et al., J. Mod. Mater.; Vol. 7, Issue 1, pp: 68-78, 2020

Alternative Building Materials in the process of their manufacture, there is waste reduction, pollution prevention, recyclability and embodied energy reduction [16]. In building operation, there is energy efficiency, conservation, nontoxic, longer life and waste management alternative leading to biodegradable, recyclable, and reusable building materials. The use of Alternative Building Materials can reduce transport costs, carbon emissions, materials costs, it also offers employment and skills development opportunities [41].

Sustainable building material must be environmentally friendly, affordable, flexible in usage and durable [42]. Alternative Building Materials such as timber stores as much as 250 $\mathrm{Kg} / \mathrm{m}^{3}$ of carbon dioxide $\left(\mathrm{CO}_{2}\right)$ and releases only $15 \mathrm{Kg} / \mathrm{m}^{3}$ into the atmosphere. In contrast, Steel, Concrete and Aluminium store no carbon dioxide while they release 5320 $\mathrm{Kg} / \mathrm{m}^{3}, 120 \mathrm{Kg} / \mathrm{m}^{3}$ and $22000 \mathrm{Kg} / \mathrm{m}^{3}$ respectively into the atmosphere. The environmental impacts of cob from a life cycle perspective as an Alternative Building Materials show that the embodied energy and carbon of cob is significantly lower than that of the other conventional materials. Therefore its utilisation can reduce global warming [41]. Also, [43] eneumerated some of the benefits of sustainable building materials to include: conserving resources to reducing environmental impacts, improving environmental quality and accruing subsequent savings through improved productivity and waste reduction.

\section{Conclusion}

The importance of Alternative Building Material for sustainable construction towards sustainable development cannot be over emphasised because global warming can be reduced if these materials are utilised. The basic importance of the materials includes the following: friendliness to the environment, affordability, durability, energy conservative alternative, recyclability; low pollution. The types of Alternative Building Materials available in the building construction industry are modified conventional industrial materials, unconventional/indigenous/traditional materials and modified unconventional/traditional indigenous material. Specifically the materials include: laterite soil, brick wastes, rice husk ash, burnt refuse ash, fly ash, periwinkle shell powder, earthworm cast, .pulverized burned clay, straw, bamboo, coconut fibres, refia palm fibres, wood shavings, wood tendons, cotton fibre, sisal fibre, stone dust, broken bricks, laterite, laterite soil, palm kernel shell, periwinkle shell, groundnut shell, tubali, earth/mud blocks or bricks, laterite blocks, bamboo for roofing \& ceiling, palm front roofing, wood, clay/mud plaster, compressed earth bricks, palm oil, bitumen emulsion, locust bean, indigo dyeing pits residue, lime, earthworm cast. The features of sustainable construction materials which Alternative Building Materials possess are ecological features, economic features, environmental features, social and functional features. Therefore, Alternative building materials can play a crucial role for sustainable construction towards sustainable development, these materials are capable of meeting basic demands of sustainability which includes their ability to protect the environment, provide people with economic benefits as well as providing social value to the communities as well as the society at large. The study recommends the integration of the entire stakeholders in the construction industry as it regards to the utilisation of the Alternative Building Materials for sustainable construction towards sustainable development. The study also recommends the cataloguing of all Alternative Building Materials so as to create awareness to all the potential clients and stakeholders of the industry regarding their availability and importance that has been established.

\section{Declarations}

\subsection{Study Limitations}

To obtain literature materials on Alternative Building Materials was a big challenge due to lack of finance to buy data and also lack of electricity to power our computer devices.

\subsection{Acknowledgments}

We wish to specifically appreciate Professor Natalia, A. Anigbogu and Dr. Daniel, M.Mallo 
both lecturers in the Faculty of Environmental Sciences of the University of Jos Building Department and Estate Management Department for their advice and encouragement in this area of knowledge gap

\subsection{Competing Interests}

There is no potential conflict of interest in this article.

\section{How to Cite this Article:}

J. Josiah Marut, J. O. . ALAEZI, and I. C. . OBEKA, “A Review of Alternative Building Materials for Sustainable Construction Towards Sustainable Development", $J$. Mod. Mater., vol. 7, no. 1, pp. 68-78, Dec. 2020. https://doi.org/10.21467/jmm.7.1.68-78

\section{References}

[1] S. Halliday, "Sustainable Construction". Science Education, Oxford: Butterworth-Heinemann. Pp, 59-85.

[2] A. U.Usman, M. F. Khamidi \& T. Hassan, "Sustainable building material for green building construction, conservation and refurbishing" Management in Construction Research Association (MiCRA) Postgraduate Conference. 2018.

[3] CIB (International Council for research and innovation in Building and construction), "Agenda 21on sustainable construction". Association of Research in Construction Management, vol. 2, pp 49, 2011. http://www.cibworld.nl:600/pages/begin/A21SCDC.ht $\mathrm{ml}$

[4] N. A Anigbogu, "Economics of Alternative construction materials: Some Conceptual Issues". Nigerian Journal of Construction Technology Management. Vol.2, issue 1, pp. 93-96, 1999.

[5] J. Sharman, "Alternative housing: a different approach to materials, styles and community thinking (Part one)" 2016.

[6] M. S. Ali, S. Shukri, M. Patel, A. Ahad, "Alternative Building Materials for Sustainable Development in Ethiopian Construction. International Research Journal of Engineering and technology, vol. 7, no. 6, pp. 28992903, 2020.

[7] A. Almusaed, A. Almssad, R. Z. Homod, \& I. Yitmen, "Environmental Profile on Building Material Passports for Hot Climates", Sustainability 2020, 12 (9), 3720, pp 1- 22. https://doi.org/10.3390/su12093720

[8] Constructing Excellence, "Key issues in Sustainable Construction". 12015. http://constructingexcellence.org.uk/key-issues-insustainable

[9] Y..Songa, H. Zhang, Research on sustainability of building materials. In IMMAEE 2018 IOP Conference Series: Materials Science and Engineering; IOP Publishing Ltd.: Bristol, UK, 2018; Volume 452. https:/doi.org/10.1088/1757-899X/452/2/022169

[10] J. Hook, "Top 5 Key issues impacting Sustainable Construction" 2019. https://www.buildsoft.com.au/blog/top-5-key-issuesimpacting-sustainable-construction
[11] U. N. United Nations, "The Sustainable Development Goals Report 2017”. https://unstats.un.org/sdgs/files/report/2017/TheSustain ableDevelopmentGoalsRepo

[12] K. N. Sheth, "Sustainable building materials used in green buildings". 9th International Conference on Engineering and Business Education \& 6th International Conference on Innovation and Entrepreneurship, 135143, 2016.

[13] Buckley, S. "Sustainable Construction \& Building Materials" Architecture Design, 2020. https://www.architectureanddesign.com.au/features/list/ sustainable-construction-building-materials

[14] B.C.A, "Building and Construction Authority Singapore. Sustainable Construction Materials for Buildings" 2007. https://www.bca.gov.sg/SustainableConstruction/others/ $\mathrm{s}$

[15] L. Shen, X. Ou and C. Feng, "Sustainable Construction" Chapter 1, pp 1-15, 2018. http://ira.lib.polyu.edu.hk/bitstream/10397/181/4/SDPBook-Chap-1.pdf

[16] A. U.Usman, M. F. Khamidi \& T. Hassan, "Sustainable building material for green building construction, conservation and refurbishing" 2018.

[17] J. Willis, "Sustainability theory" 2019. Available: http://www.berkshirepublishing.com/asset

[18] UNECA, African Union (AU), \& the African Development Bank (AfDB), "Final Report of the Africa Regional Consultative Meeting on Sustainable Development Goals (Experts Segment)". Addis Ababa, Ethiopia; UNECA, 2019.

[19] H. Snyder, "Literature review as a research methodology: An overview and guidelines". Journal of Business Research vol. 104, pp. 333-339, 2019. https://doi.org/10.1016/j.jbusres.

[20] U. N. United Nations, "The Sustainable Development Goals Report 2017".

[21] F. K. Omole, \& A. I. Bako, "Analysis of the problems and prospects in the use of local building materials: review of literature". Civil and Environmental Research, vol. 3 no. 11, pp. 1-7, 2019

[22] I. D. Isa, L. Xue, \& S.G. Dalibi,. "Vernacular architecture of northern Nigeria in the light of sustainability". International Conference on Environmental and Energy Engineering. Earth and Environmental Science, vol. 63, pp. 1-10, 2018. https:doi.org/10.1088/1755-1315/63/1/012034

[23] H. Snyder, "Literature review as a research methodology: An overview and guidelines". Journal of Business Research vol. 104, pp. 333-339, 2019.

[24] C. Okoli, \& K. Schabram, "A Guide to conducting a systematic literature review of information systems research" 2019.

[25] O. O. Odunjo, "Laterite building material and sustainable housing production in Nigeria". Merit Research Journal of Environmental Science and Toxicology vol. 2 no. 3, pp. 039-043, 2019.

[26] O. Ikechukwu, \& B. U. Iwuagwu, "Traditional building materials as a sustainable resource and material for low cost housing in Nigeria: Advantages, Challenges and the Way Forward" 2018. International Journal of Research in Chemical, Metallurgical and Civil Engg, vol. 3, pp. 247-252.

[27] O.Kayode, \& A.E. Olusegun, "Local building materials: a tool towards effective low-income housing in Nigeria". 
Johnson Josiah Marut et al., J. Mod. Mater.; Vol. 7, Issue 1, pp: 68-78, 2020

Middle-East Journal of Scientific Research, vol.18 no.4, pp. 492-497, 2018.

[28] O. F. Job, \& J.E. Afunanya, "Innovation in material production and utilisation in the building industry". Proceeding of the $46^{\text {th }}$ Buildings' Conference/Annual General Meeting Edo 2016, pp. 23-32

[29] B. A. Akinyemi, A. Elijah, A. Oluwasegun, D. T. Akpenpuun, O. Glory,The use of red earth, lateritic soils and quarry dust as an alternative building material in sandcrete block", African Scientific Journal, pp 1-7, 2020. Available: https://doi.org/10.1016/j.sciaf.2020.e00263

[30] I.M. Oyemogun, D.O. Adeagbo, \& J.J Marut, “An assessment of alternative materials use in the Nigerian construction industry". Nigerian Journal of Construction Technology Management, vol. 12 no. 2, pp. 113-117, 2011.

[31] J. Kim, \& B. Rigdon "Sustainable architecture module: qualities, use, and examples of sustainable building materials", Sustainable Building Materials, pp 1-44, 1998.

[32] C. Bristow, "Identifying barriers to the use of natural building materials in mainstream construction in Ireland" MSc. Architectural Engineering: Environmental Design, pp 1-98 2019. University of Bath.

[33] C. MacDougall, "Natural Building Materials in Mainstream Construction: Lessons from the U. K". Journal of Green Building, vol.3 no. 3, pp. 1-14, 2018.

[34] M. Spišáková, \& D. Mačková, “The use potential of traditional building materials for the realization of structures by modern methods of construction". Selected Scientific Papers-Journal of Civil Engineering, vol.10 no. 2, pp. 127-138, 2020.

[35] Construction Crushers, "Crushers for road construction" Ganzhou Eastman Technology Co., Ltd. 2011.

[36] S. W. Baba, \& B. Y. Anas, "Low Cost Housing in Nigeria: A Case of Incorporating Alternative Construction Materials (ACM) as Components". Journal of Engineering and Energy Research vol.2, no.1, pp 5564, 2018.

[37] L. D. Antoli, \& U.D. Matteo, "Building energy and environment performance system. Building Systems", vol.24, no. 2, pp. 61-68, 2019.

[38] H. Danso, "Identification of Key Indicators for Sustainable Construction Materials", Advances in Materials Science and Engineering, vol. 2018, Article ID 6916258, 7 pages, 2018. https://doi.org/10.1155/2018/6916258

[39] N. Sunke, \& F. Schultman, "Requirements for sustainable construction materials and components" 2019.

[40] B.Smaranda, R. Liliana \& R. Radu, "What characteristics define ecological building materials". Proceedings of the 7th IASME/WSEAS International Conference on Heat Transfer, Thermal Engineering and Environment (HTE) 2019.

[41] L, Ben-Alon, V. Loftness, K.T. Harries, \& E.C. Hameen , "Integrating earthen building materials and methods into mainstream housing projects throughout design, construction, and commissioning stages" 2019.

[42] J. Abimaje, \& A. N. Baba, "An assessment of timber as a sustainable building material in Nigeria". International Journal of Civil Engineering, Construction and Estate Management, vol. 1, no. 2, pp. 39-46, 2019.

[43] Ecologically Sustainable Development: "Environmentally sustainable building materials
Publish your research article in AIJR journals-

$\checkmark$ Online Submission and Tracking

$\checkmark$ Peer-Reviewed

$\checkmark \quad$ Rapid decision

$\checkmark \quad$ Immediate Publication after acceptance

$\checkmark$ Articles freely available online

$\checkmark \quad$ Retain full copyright of your article.

Submit your article at journals.aijr.in

Publish your books with AIJR publisher-

$\checkmark \quad$ Publish with ISBN and DOI.

$\checkmark$ Publish Thesis/Dissertation as Monograph.

$\checkmark$ Publish Book Monograph.

$\checkmark$ Publish Edited Volume/ Book.

$\checkmark$ Publish Conference Proceedings

$\checkmark \quad$ Retain full copyright of your books.

Submit your manuscript at books.aijr.org 